\title{
Analisa Postur Tubuh Kegiatan Input Data pada PT ABC
}

\author{
Benedikta Anna Haulian Siboro \\ Program Studi Manajemen Rekayasa, Fakultas Teknologi Industri, Institut Teknologi Del \\ Jalan P.I. Del, Sitoluama, Balige, Kabupaten Toba Samosir, Sumatera Utara 22381 \\ Email: benedikta.siboro@del.ac.id
}

\begin{abstract}
ABSTRAK
Salah satu aktivitas berulang-ulang yang ada di perusahaan manufacturing adalah proses penginputan data yang dilakukan oleh Production Engineering (PE). Tugas yang dilakukan PE tersebut yaitu menganalisa produk yang bermasalah, kemudian menginput data tersebut secara langsung dari server database menggunakan komputer serta mengeluarkan produk tersebut tanpa harus turun langsung ke area produksi untuk melakukan aktifitas analisa. Masalah yang dihadapi adalah produk yang harusnya ter-release ke area produksi sering terhambat dan cenderung lambat dikarenakan kondisi PE yang sering tidak masuk. Dari data kehadiran menunjukkan dalam tiga bulan terakhir sebesar 48\% ketidakhadiran dikarenakan sakit. Tujuan dari penelitian ini adalah untuk mengidentifikasi risiko musculoskeletal disorders (MSDs) yang dialami oleh operator dan memberikan usulan perbaikan guna mengurangi risiko tersebut. Metode yang digunakan adalah ROSA (Rapid Office Strain Assessment). Hasil penelitian menunjukkan dengan metode ROSA kegiatan penginputan tersebut termasuk dalam level risiko tinggi yaitu enam dengan ditemukannya sandaran tangan dan punggung pada kursi serta posisi monitor yang tidak ergonomis. Penggunaan sandaran tangan dapat mempengaruhi tingginya keluhan pada bahu dan penggunaan monitor dapat mempengaruhi tingginya keluhan pada leher.
\end{abstract}

Kata kunci: input data, ROSA, risiko musculoskeletal disorders, keluhan

\section{ABSTRACT}

One of repetitive tasks at manufacturing company is data input process which is done by Product Engineer (PE). The task of PE is analyzing the problem of product, input problem issue of product to server database by computer, and release product without direct analysis activity in production area. The problem commonly found during the process is that the product that should be released to production actually come lately to production due to the absence of PE worker (around 48\% for the last three months due to health problems). The objective of this research is to identify musculoskeletal disorders of PE worker and to propose improvement in order to reduce the risk. The method that is used in this research is Rapid Office Strain Assessment (ROSA). The result shows that the input data activity is in high level risk, that is level 7. In addition, backrest and armrest of chair are not ergonomics. The use of armrests can affect to the high complaints of the shoulders and the use of monitors can affect the high complaints of the neck.

Keywords: input data, ROSA, musculoskeletal disorders risk, complaints

\section{Pendahuluan}

Proses integrasi prinsip-prinsip ergonomi dalam perancangan suatu fasilitas produksi, terutama pada suatu sistem dalam stasiun kerja semakin diperlukan [1]. Dalam suatu perancangan sistem kerja, sangat penting untuk memperhatikan elemen-elemen gerakan dari pekerja itu sendiri. Aktivitas gerakan kerja aktual yang berlangsung selama ini tanpa disadari kurang memperhatikan faktor kenyamanan dalam melakukan aktifitas kerja. Salah satu kegiatan seperti menginput data dengan menggunakan komputer jika dilakukan dengan secara berulang dan kondisi kerja yang tidak ergonomis maka akan menimbulkan kelelahan dan rasa nyeri serta agar terjadi ketidakseimbangan beban tubuh dengan beban kerja, sehingga diperlukan perbaikan melalui mendesain, redesain atau modifikasi alat fasilitas kerja.

Production Engineering (PE) adalah salau satu department yang ada di PT ABC, yang bertugas menganalisa produk yang bermasalah kemudian menginput data tersebut secara langsung dari server database menggunakan computer serta me-release produk tersebut tanpa harus turun langsung ke area produksi untuk melakukan aktifitas analisa. Aktifitas kerja yang berulang-ulang dan sebagian besar aktifitas kerja dilakukan duduk di depan komputer 
untuk selalu meng-update device yang bisa di-release ke area produksi. Berdasarkan hasil wawancara yang dilakukan terhadap operator yang berjumlah 12 orang diperoleh 10 dari 12 atau 84\% mengeluh sakit pada area bahu, tulang belakang dan leher yang disebabkan oleh posisi kerja pekerja yang lebih sering duduk dan fokus terhadap komputer. Menurut Sutalaksana [2] hal ini dimungkinkan karena fasilitas kerja yang kurang ergonomis dengan dimensi objek yang tidak bersesuaian dengan pemakainya.

Menurut Kroemer [3] office ergonomics merupakan penerapan dari ilmu ergonomi yang meliputi keseluruhan lingkungan kerja dan alat kerja yang digunakan seperti perangkat komputer dan kursi. Bahaya di perkantoran umumnya disebabkan oleh postur kerja yang salah, gerakan berulang dan posisi yang tetap dalam jangka waktu yang lama. Salah satu cedera yang paling sering dihadapi adalah musculoskeletal disorsders (MSDs) atau cedera pada sistem otot rangka. Apabila pekerja mengalami gangguan tersebut, akan memungkinkan terjadinya penurunan konsentrasi terhadap pekerjaannya sehingga mengalami ketidaknyaman dan cepat lelah yang pada akhirnya mengakibatkan produktivitas menurun [4]. Faktor yang dapat menyebabkan terjadi keluhan otot rangka adalah peregangan otot yang berlebihan, aktivitas berulang, sikap kerja tidak alamiah, faktor penyebab sekunder, penyebab kombinasi seperti pekerja harus melakukan aktivitas angkat angkut di bawah tekanan panas matahari seperti yang dilakukan oleh para pekerja bangunan.

Salah satu metode office ergonomics [5] di mana cara penilaian metode ini dirancang untuk mengukur risiko cedera pekerja yang berhubungan dengan penggunaan komputer serta menetapkan tingkat tindakan perubahan berdasarkan laporan dari ketidaknyamanan pekerja itu sendiri adalah ROSA (Rapid Office Strain Assessment). Faktor-faktor risiko dari pekerja yang berhubungan dengan komputer diidentifikasikan dari desain ruangan kerja itu sendiri yaitu kursi, monitor, telepon, mouse, dan keyboard (Gambar 1). Faktor risiko tersebut diberi nilai dari mulai 1 sampai 3. Pada nilai akhir ROSA akan diperoleh nilai antara 1 sampai 10. Jika nilai akhir yang diperoleh lebih besar dari 5 maka dianggap berisiko tinggi dan harus dilakukan pengkajian lebih lanjut pada tempat kerja yang bersangkutan. ROSA terbukti menjadi metode yang efektif dan dapat diandalkan untuk mengidentifikasi faktor risiko pekerja yang berhubungan dengan penggunaan komputer terkait dengan ketidaknyamanan pekerja itu sendiri. Nilai tertinggi pada sub-bagian didapatkan dari hasil maksimum dari semua kemungkinan faktor risiko individu dan durasi pekerjaan yang dilakukan. Nilai tertinggi yang mungkin dapat dicapai adalah 10, nilai 10 dipilih agar pengguna dengan mudah memahami sistem penilaian 1-10 yang akan mencerminkan jumlah risiko yang hadir dalam workstation [5]. Apabila nilai akhir yang diperoleh lebih besar dari 5 maka dianggap berisiko tinggi dan harus dilakukan pengkajian lebih lanjut pada tempat kerja yang bersangkutan.

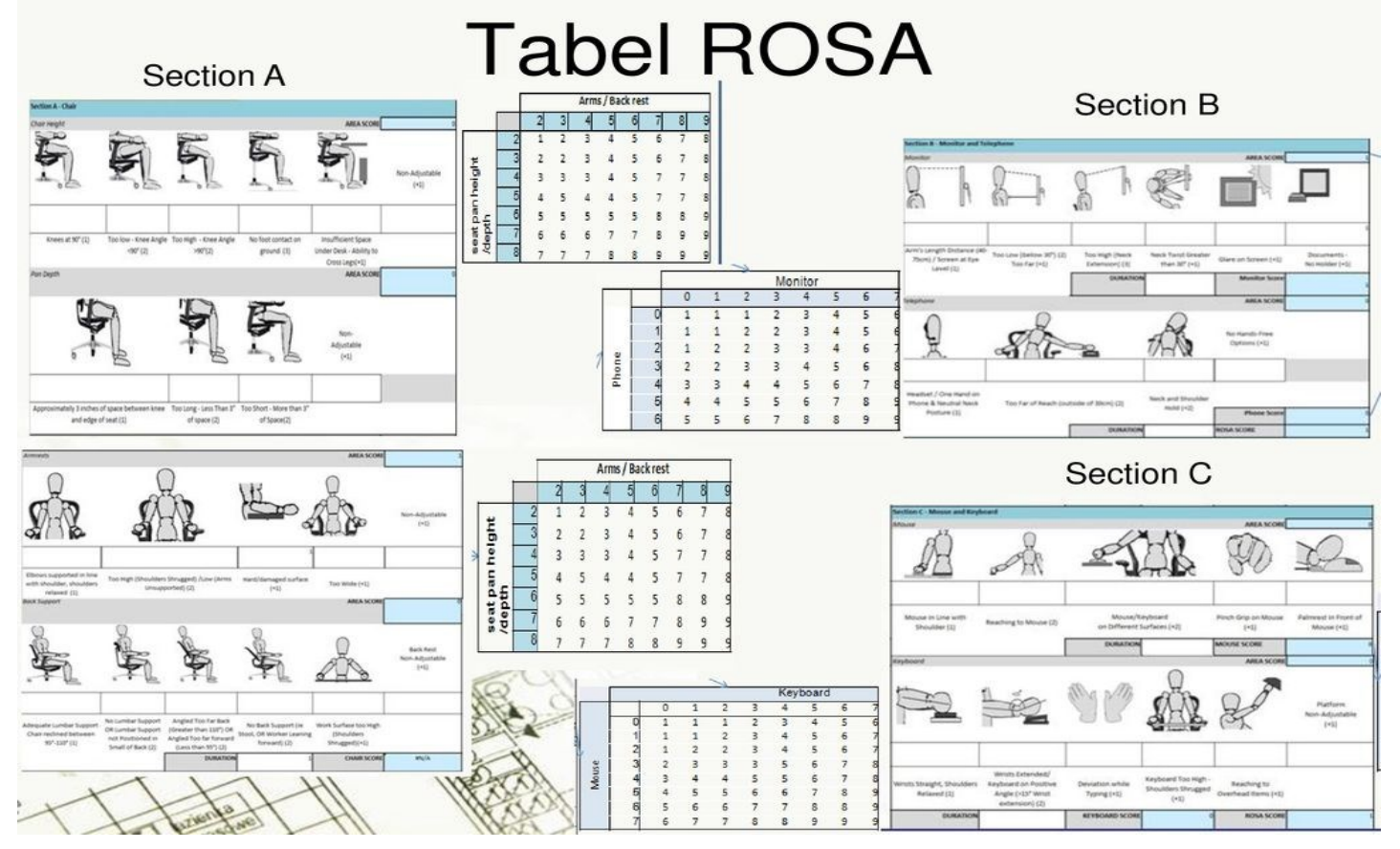

Gambar 1. Contoh penilaian risiko kerja dengan metode ROSA

Penelitian mengenai aplikasi penggunaan ROSA sudah banyak dilakukan, di antaranya oleh Damayanti dkk. [6] yang meneliti postur tubuh pekerja di Departemen Publishing. Pada departemen tersebut, faktor risiko tertinggi pada bagian editor dengan skor 9 disusul pada bagian publishing, art creative, setting layout dengan skor rata-rata 7 sehingga perlu dilakukan perbaikan fasilitas kerja dalam waktu dekat. Penelitian lain juga dilakukan oleh 
Oesman dan Purwanto [7] yang meneliti posisi dan sikap kerja yang tidak alamiah di Bagian Biro Administrasi Akademik Lembaga XXX di Yogyakarta.

Dari gambaran di atas, maka tujuan dari penelitian ini adalah mengidentifikasi risiko kerja PE dan memberikan usulan fasilitas kerja yang ergonomis yang diharapkan dengan adanya fasilitas kerja tersebut, postur kerja yang mengalami keluhan MSDs seperti otot di tulang belakang, lengan, kaki, dan leher dapat direduksi.

\section{Metode Penelitian}

Objek dalam penelitian ini adalah 12 pekerja pada PE testing line production di PT ABC. Pengumpulan data dilakukan dengan memberikan kuisioner SNQ (Standard Nordic Questionnaire) kepada pekerja tersebut untuk mengetahui area anggota tubuh yang dirasa sakit saat melakukan penginputan data dan melakukan pengamatan langsung terhadap postur tubuh karyawan yang bekerja pada departemen tersebut (Gambar 2). Pengumpulan data dilakukan dengan melakukan pengisian lembaran penilaian ROSA. Dalam pengisian lembaran tersebut, akan dilakukan pengamatan terhadap posisi pekerja, kondisi fasilitas kerja yang dilakukan dengan pengambilan gambar menggunakan kamera, dan pengukuran fasilitas kerja yang digunakan oleh pekerja tersebut.

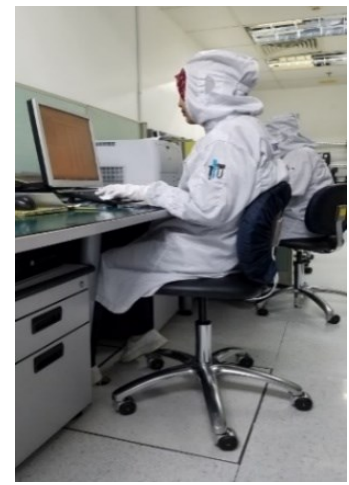

Gambar 2. Postur tubuh PE pada saat input data

\section{Hasil dan Pembahasan}

\section{Analisa Keluhan Pekerja}

Data ini didapat dengan cara menyebarkan kuesioner SNQ dengan tujuan untuk mengetahui bagian tubuh yang mengalami keluhan pada saat PE melakukan aktivitas kerja. Hasil menunjukkan bahwa persentase keluhan secara keseluruhan terhadap 12 anggota $\mathrm{PE}$, maka rata-rata PE mengalami keluhan terbesar pada bagian tubuh ditunjukkan pada Gambar 3.

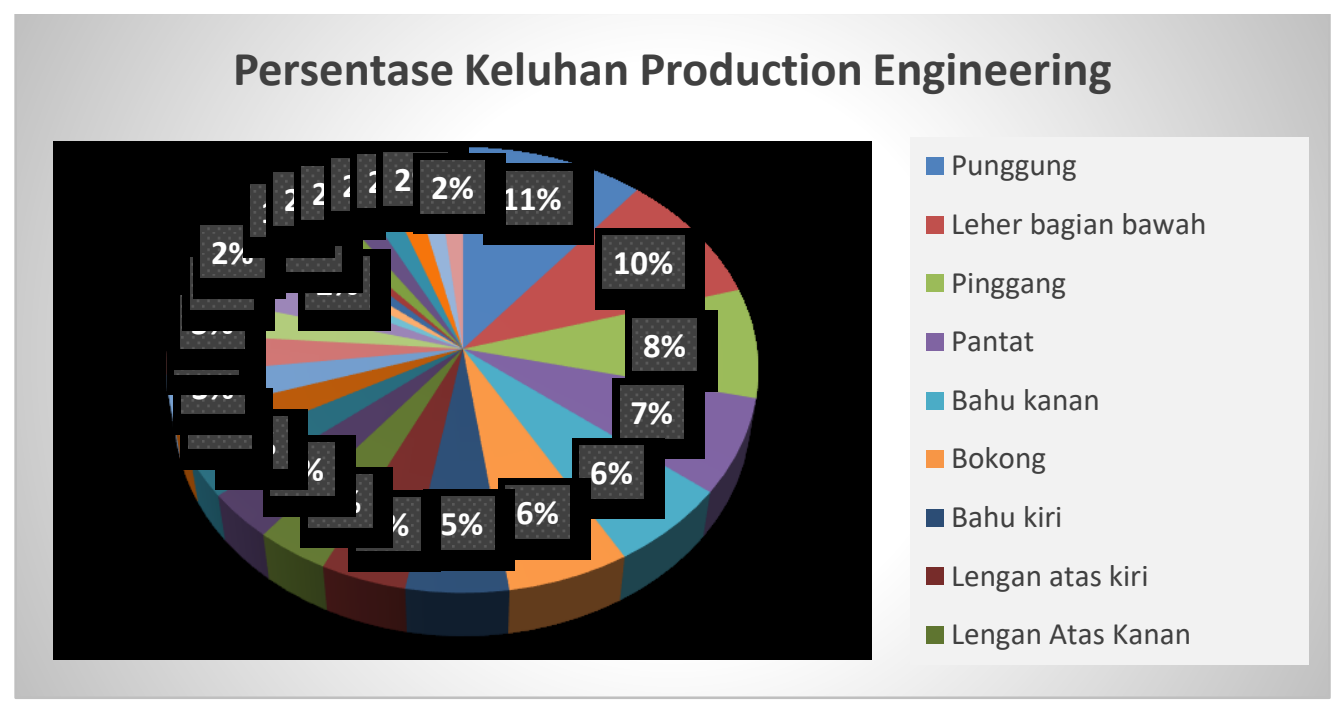

Gambar 3. Persentase keluhan dengan metode SNQ 
Dari Gambar 3 menunjukkan bagian tubuh yang sering dikeluhkan oleh PE adalalah punggung 10,95\%, Leher bagian bawah 9,62\%, pinggang 7,95\%, Pantat 6,95\%, Bahu kanan 6.12\%, bokong 6,12\% dan bahu kiri 5,13\%. Keluhan musculoskeletal pada beberapa bagian tubuh PE Member diatas dimungkinkan karena posisi kerja yang kurang ergonomis pada saat melakukan pekerjaan, dikarenakan fasilitas kerja yang kurang ergonomis sehingga PE bekerja dengan posisi kerja yang tidak ergonomis. Untuk mengatasi hal tersebut perlu dilakukan perancangan fasilitas kerja yang ergonomis yaitu fasilitas kerja yang efektif, nyaman, dan aman. Sehingga dapat merubah atau menghilangkan beberapa posisi kerja yang tidak ergonomis yang dapat menimbulkan keluhan musculoskeletal.

\section{Analisa Postur Kerja dengan Metode ROSA}

Dari hasil penilaian diketahui bahwa skor terjadi pada area sandaran tangan dan punggung. Berdasarkan metode ROSA faktor risiko yang memiliki nilai risiko paling tinggi yaitu pada sandaran punggung, sandaran tangan dan monitor. Pada sandaran punggung dari nilai 5, nilai tertinggi yang ada pada pekerja yaitu 7 . Pada sandaran tangan dari nilai 5, nilai tertinggi yang ada pada pekerja yaitu 5 sehingga sangat mempengaruhi hasil dari skor A. Sedangkan pada monitor dari nilai 5 , nilai tertinggi yang ada pada pekerja yaitu 4. Bagian yang memiliki faktor risiko yang tinggi dapat mempengaruhi tingginya keluhan yang dirasakan oleh pekerja. Pada penggunaan sandaran punggung dapat mempengaruhi tingginya keluhan pada punggung bagian atas dan bahu. Pada penggunaan sandaran tangan dapat mempengaruhi tingginya keluhan pada bahu dan penggunaan monitor dapat mempengaruhi tingginya keluhan pada leher. Hasil Akhir menunjukkan bahwa berada pada level 6 yaitu dianggap berisiko tinggi dan harus dilakukan pengkajian lebih lanjut pada tempat kerja yang bersangkutan.

Tabel 1. Skor pada masing-masing penilaian dalam Metode ROSA

\begin{tabular}{c|c|c|c|c|c|c|c}
\hline Pekerja ke & $\begin{array}{c}\text { Tinggi+ } \\
\text { Dalam } \\
\text { Kursi (A1) }\end{array}$ & $\begin{array}{c}\text { Sandar Tangan } \\
\text { + Punggung } \\
\text { (A2) }\end{array}$ & $\begin{array}{c}\text { Skor A } \\
\text { (A1+A2) }\end{array}$ & $\begin{array}{c}\text { Skor B } \\
\text { (Monitor+ } \\
\text { Telepon) }\end{array}$ & $\begin{array}{c}\text { Skor C } \\
\text { (Mouse+ } \\
\text { Keybord) }\end{array}$ & $\begin{array}{c}\text { Hasil } \\
\text { Skor BC }\end{array}$ & $\begin{array}{c}\text { Hasil } \\
\text { Akhir }\end{array}$ \\
\hline 1 & 4 & 7 & 6 & 4 & 3 & 4 & 6 \\
3 & 5 & 7 & 6 & 3 & 3 & 3 & 6 \\
4 & 4 & 7 & 6 & 4 & 2 & 4 & 6 \\
5 & 5 & 6 & 5 & 3 & 3 & 3 & 5 \\
6 & 4 & 7 & 6 & 3 & 4 & 6 \\
7 & 5 & 7 & 6 & 4 & 3 & 4 & 6 \\
8 & 5 & 6 & 5 & 4 & 3 & 3 & 6 \\
9 & 5 & 6 & 5 & 3 & 3 & 3 & 5 \\
10 & 5 & 7 & 6 & 4 & 3 & 4 & 6 \\
11 & 5 & 7 & 6 & 4 & 3 & 4 & 6 \\
12 & 5 & 6 & 5 & 4 & 2 & 4 & 6 \\
\hline Rata-rata & $\mathbf{5}$ & $\mathbf{7}$ & $\mathbf{6}$ & 4 & $\mathbf{3}$ & $\mathbf{4}$ & $\mathbf{6}$ \\
\hline
\end{tabular}

\section{Usulan Perbaikan}

Pengamatan dengan menggunakan metode ROSA menunjukkan kondisi kursi yang menyangkut sandaran dan punggung dengan skor 5-7 menunjukkan perlunya perbaikan kursi. Perbandingan kursi kerja aktual PE dengan kursi kerja usulan dapat dilihat pada saat bekerja dapat dilihat pada Tabel 2 yang menunjukkan bahwa diperlukan tindakan perbaikan pada fasilitas kerja kerja. Pada kursi kerja aktual sandaran punggung kaku dan tidak bisa di disesuaikan, pada rancangan kursi kerja usulan ditambahkan alat yang dapat menyesuaikan sandaran punggung dan lebih fleksible dengan kemiringan maksimal dari sandaran punggung adalah $110^{\circ}$ sesuai untuk mengurangi risiko cedera daerah lumbar [8], agar dapat disesuaikan dengan bentuk dari punggung masing-masing PE member sehingga dapat mengurangi rasa sakit pasa area punggung dan pinggang. Untuk mengurangi rasa sakit pada area pantat dan lumbar support diberi busa yang lebih tebal, supaya dapat mengurangi rasa sakit jika terlalu lama duduk.

Fasilitas yang kurang sesuai dengan standar dan kurangnya kesadaran pekerja, selain dari penjelasan di atas terdapat satu faktor yang mempengaruhi tingginya risiko yang dirasakan pekerja yaitu durasi penggunaan komputer. Karena seluruh pekerja menggunakan komputer lebih dari empat jam. Pada ROSA durasi penggunaan komputer tidak akan mempengaruhi risiko jika kurang dari empat jam. Lamanya penggunaan komputer ini 
sebaiknya diimbangi dengan melakukan peregangan otot pada saat bekerja. Jika hasil penilaian postur kerja aktual dibandingkan dengan penilaian postur kerja usulan terlihat bahwa terjadi penurunan risiko kerja. Dengan dibuatnya rancangan kursi yang ergonomis dan sesuai dengan kondisi anthropometri dari PE terjadi penurunan level MsDs yang terlihat dari adanya perubahan fasilitas kerja yaitu berupa kursi kerja yang dirancang sesuai dengan keinginan konsumen dan kondisi dari tubuh pekerja itu sediri. Sesuai dengan prinsip ergonomi bahwa fasilitas kerja yang menyesuaikan kondisi tubuh dari pekerja, bukan sebaliknya. Hal ini berakaitan dengan kesehatan dan kenyamanan perkerja agar bisa memaksimalkan hasil dari pekerjaannya. Pada pengamatan penggunaan monitor dan mouse serta peralatan yang berhubungan dengan komputer menunjukkan skor rata-rata 3-4 yang artinya kondisi ini masih aman.

Tabel 2. Perbandingan kursi kerja aktual dan usulan

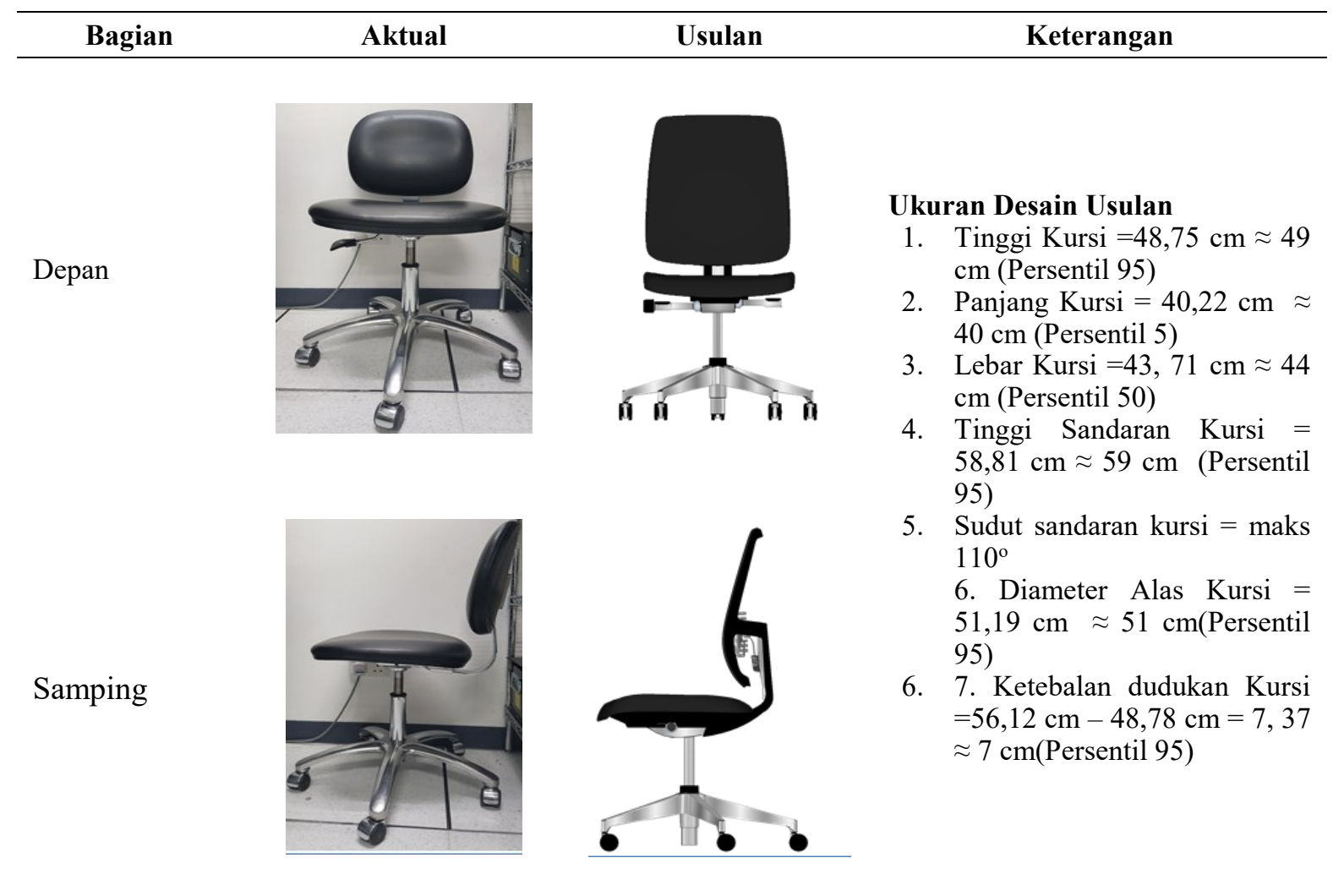

\section{Kesimpulan dan Saran}

Dari hasil penelitian diatas, maka dapat disimpulkan beberapa hal yaitu :

a. Berdasarkan hasil penyebaran kuesioner SNQ Tingkat keluhan yang dialami Production Engineering (PE) pada saat bekerja yaitu pada bagian leher bagian bawah, bahu kiri, bahu kanan, lengan atas bagian kiri, punggung, pinggang dan pantat.

b. Metode ROSA menunjukkan level risiko tinggi yaitu 6 yang memerlukan adanya perbaikan fasilitas kerja yaitu kursi dengan rancangan sesuai dengan suara pengguna dengan sandaran punggung dengan sudut kemiringan maksimum $110^{\circ}$ dan memberikan kenyamanan saat digunakan yaitu dengan adanya penambahan busa yang tebal pada bagian dudukan pantat.

\section{Daftar Pustaka}

[1] Sutanto A. Disain Stasiun Kerja Yang Ergonomis Dengan Metode Virtual Manufacturing. Jurnal Optimasi Sistem Industri Vol. 2 No.2. 2007. hal 69-74

[2] Sutalaksana, I. Teknik perancangan sistem kerja. Bandung: Institut Teknologi Bandung, Jilid 1. 2006.

[3] Kroemer, Anne D.; Kroemer, Karl H.E., OFFICE ERGONOMICS-Ease \& Efficiency at Work. Taylor \& Francis, CRC. Florida. 2017

[4] Setyaningsih L.; Siboro B.A.H.; Purbasari A. Perancangan Footrest untuk Mengurangi Kelelahan Operator pada Bagian Kaki di Cell S/A Coil XS156 di PT.ABC, Jurnal PASTI Vol X No.2 hal 126-137. 2016. 
[5] Sonne, M; Villalta, DL; Andrews, DM. "Development and evaluation of an office ergonomic risk checklist: ROSA--rapid office strain assessment”. Applied Ergonomics. Vol. 43, No.1, January 2012, hal 98-108. 2012

[6] Damayanti R.H, Iftadi I, Astuti R.D., Analisis Postur Kerja Pada PT. XYZ menggunakan Metode ROSA (Rapid Office Strain Assessment), Jurnal Ilmiah Teknik Industri Vol. 13 No. 1, 2014, hal 1-7.

[7] Oesman T.I, Purwanto. Penilaian Postur Kerja Guna Evaluasi Tingkat Risiko Dengan Metode Rapid Office Strain Assessment (ROSA). Prosiding Saintiks FTIK Unikom Vol 2. 2017. hal 37-42.

[8] Kroemer, K; Kroemer, H; Elbert, K.K., Ergonomics-How to Design for Ease and Efficiency. Prentice Hall. New Jersey, 2001. 